\title{
Analysis of a Severe Regional Haze-fog-dust Episode over North China in Autumn by Using Multiple Observation Data
}

\author{
Yingxiao Tang ${ }^{1,2}$, Suqin Han ${ }^{1,2 *}$, Qing Yao ${ }^{1,2}$, Ziying Cai ${ }^{1,2}$, Yulu Qiu ${ }^{3}$, Jin Feng ${ }^{4}$ \\ ${ }^{1}$ Tianjin Environmental Meteorological Center, Tianjin 300074, China \\ ${ }^{2}$ CMA-NKU Cooperative Laboratory for Atmospheric Environment-Health Research, Tianjin 300074, China \\ ${ }^{3}$ Environmental Meteorology Forecast Center of Beijing-Tianjin-Hebei, Beijing 100089, China \\ ${ }^{4}$ Institute of Urban Meteorology, China Meteorological Administration, Beijing 100089, China
}

\begin{abstract}
The mixing of dust and haze is an important factor in the variation of fine particles. In this study, multiple observation data were used to analyze the characteristics and formation of a haze-fog-dust event that occurred in North China between November 23 and November 30 of 2018. This episode can be roughly divided into two stages, haze-fog and dust, with the transition occurring on November 27. Our analysis shows that stable weather conditions and temperature inversions in North China caused the haze-fog event (November 23-26), during which the $\mathrm{PM}_{2.5}$ concentration gradually increased. After November 27, the arrival of cold air accompanied by dust activity rendered meteorological conditions favorable to air quality in the northern part but not the central or southern part of North China. Instead, continuous adverse conditions and the dust backflow, which trapped dust aerosols in the southern part of North China for nearly two days, were responsible for high $\mathrm{PM}_{2.5}$ concentrations in Jinan and Zhengzhou after November 27 (146 and $156 \mu \mathrm{g} \mathrm{m}^{-3}$ vs. 114 and $144 \mu \mathrm{g} \mathrm{m}^{-3}$ before November 27, respectively). This study highlights the effect of dust transport on regional environmental pollution during the autumn and the winter.
\end{abstract}

Keyword: Air pollution; Haze; Dust; Atmospheric aerosols; Fine particles.

\section{INTRODUCTION}

Fog and haze are common weather phenomena that dramatically decrease visibility. Moreover, fog and haze are often associated with air pollution events, which greatly threaten public health and impact atmospheric radiation and regional climates (Huebert et al., 2003; Yang et al., 2010; Quan et al., 2011; Chen et al., 2013; Huang et al., 2014; Li et al., 2016a). With the acceleration of urbanization, hazefog events caused by adverse weather conditions have occurred frequently in the North China Plain, Yangtze River Delta, Sichuan Basin, and Pearl River Delta in recent years (Kaiser and Qian, 2002; Andreae et al., 2008; Fu et al., 2008; Zhang et al., 2012; Zhao et al., 2013). On the other hand, North China is near the Gobi Desert, which is one of the largest deserts in the world (Ginoux et al., 2001; Prospero et al., 2002), and it causes North China to be frequently influenced by dust storms. Simultaneously, the desert dust aerosols can also harm public health and alter the radiation budget (Griffin, 2007; Chan and Yao, 2008; Uno et al., 2009).

\footnotetext{
* Corresponding author.

E-mail address: sq_han@126.com
}

Numerous studies have been conducted to investigate haze-fog pollution. These studies showed that high emissions of urban pollutants, the height of the planetary boundary layer (PBL) and relative humidity (RH) were key factors impacting the formation and evolution of haze pollution (Sun et al., 2013; Guo et al., 2014; Han et al., 2014; Zheng et al., 2015; Wang et al., 2016; Liu et al., 2018). By analyzing a severe haze event in Beijing in September 2011, Liu et al. (2013) found that the stable conditions at the surface, the decreased PBL height, and the high pollution emissions were crucial to the formation and evolution of this haze episode, with a maximum $\mathrm{PM}_{2.5}$ mass concentration of $220 \mu \mathrm{g} \mathrm{m}^{-3}$. A weak East Asian winter monsoon often provides a favorable meteorological background for haze generation. Zhang et al. (2014) analyzed the meteorological conditions in a severe haze event over eastern China during January 2013. A weak East Asian winter monsoon resulted in nearsurface anomalous inversions, such as weak surface winds and weak vertical shear of horizontal winds, which was conducive to the maintenance and development of a haze-fog event. Dust events can affect downstream meteorological conditions and air quality during the transport process. Zhang et al. (2005) revealed that the wind speed increased and RH decreased when a dust storm occurred, and these results were accompanied by increased mixing in the 
boundary. From April 23 till 25, 2009, a strong dust storm occurred in Inner Mongolia, which affected China from north to south and affected Guangzhou last. The results showed that the $\mathrm{PM}_{10}$ concentration in Guangzhou on dusty days was two times higher than that on non-dusty days (Fan et al., 2013).

The end of haze-fog events is usually due to the effect of cold air, and strong cold air likely accompanied the dust events that occurred (Wang et al., 2014; Wang et al., 2015). During the transport of dust aerosols, the fine particles in the atmosphere can be affected by catalytic and heterogeneous chemical processes (Dentener et al., 1996; Sullivan et al., 2007; Fairlie et al., 2010). Moreover, the mixing of dust and anthropogenic pollutants also affects the downstream areas in dust transport (Sun et al., 2005; Li et al., 2012; Tao et al., 2014a; Tao et al., 2014b). In March 2013, several extreme haze events occurred in Beijing, with dust events occurring in northwestern China; Tao et al. (2014a) divided these haze events into two groups: one group occurred in stagnant weather with a $\mathrm{PM}_{2.5}$ concentration below $200 \mu \mathrm{g} \mathrm{m}^{-3}$ over 1-2 days, and the other group was formed under continuous and intense temperature inversion conditions. The latter events were accompanied by the effects of dust aerosols with a $\mathrm{PM}_{2.5}$ concentration exceeding $\sim 400 \mu \mathrm{g} \mathrm{m}^{-3}$. Moreover, the transported desert dust was further mixed with anthropogenic pollutants as it spread to northern China. Tao et al. (2014b) reported that the dust plumes more than $2 \mathrm{~km}$ thick above the haze layers were very important in the formation of the extreme haze pollution event in January 2013. These studies mostly focused on the analysis of a single city and the formation of haze-fog while neglecting the mixture of dust and anthropogenic pollutants in the formation of fine particles. Furthermore, understanding the connection and interactions between dust aerosols and anthropogenic pollutants is crucial to improving regional environmental pollution and air quality prediction.

Based on joint ground and satellite observations, a hazefog-dust event over northern China from November 23 till 30, 2018, was analyzed in this study. First, the hourly pollutants and meteorological data in different cities were analyzed to confirm the different episodes in this event. Second, the spatial and temporal distributions of the meteorological conditions, atmospheric vertical structure, and optical properties were analyzed to explain the formation of haze-fog-dust events. Moreover, the effect of pollutant and dust mixtures on the formation of pollution over downstream regions was discussed.

\section{DATA AND METHODS}

From November 23 till 30, 2018, a severe regional hazefog episode occurred over northern China and was followed by airborne dust that affected these regions, including Beijing, Tianjin, Hebei, Henan, and Shandong Provinces. Fig. 1 shows the locations of the major cities investigated in this study.

\section{Air Quality and Meteorological Data}

Currently, the Ministry of Ecology and Environment of the People's Republic of China publishes hourly concentrations of $\mathrm{PM}_{10}, \mathrm{PM}_{2.5}$, sulfur dioxide $\left(\mathrm{SO}_{2}\right)$, nitrogen dioxide $\left(\mathrm{NO}_{2}\right)$, carbon monoxide $(\mathrm{CO})$, and ozone $\left(\mathrm{O}_{3}\right)$ in major cities (http://www.mee.gov.cn/). The hourly surface meteorological data are available from the China Meteorological Data Service System (http://data.cma.cn/). These pollutant concentrations and meteorological data were used to confirm the formation of a haze-fog-dust episode. In this study, we analyzed the hourly air quality and meteorological data from 6 cities: Beijing, Tianjin, Shijiazhuang, Jinan, Qingdao, and Zhengzhou (Fig. 1). Sounding data were used in this study to investigate the variation in vertical meteorological

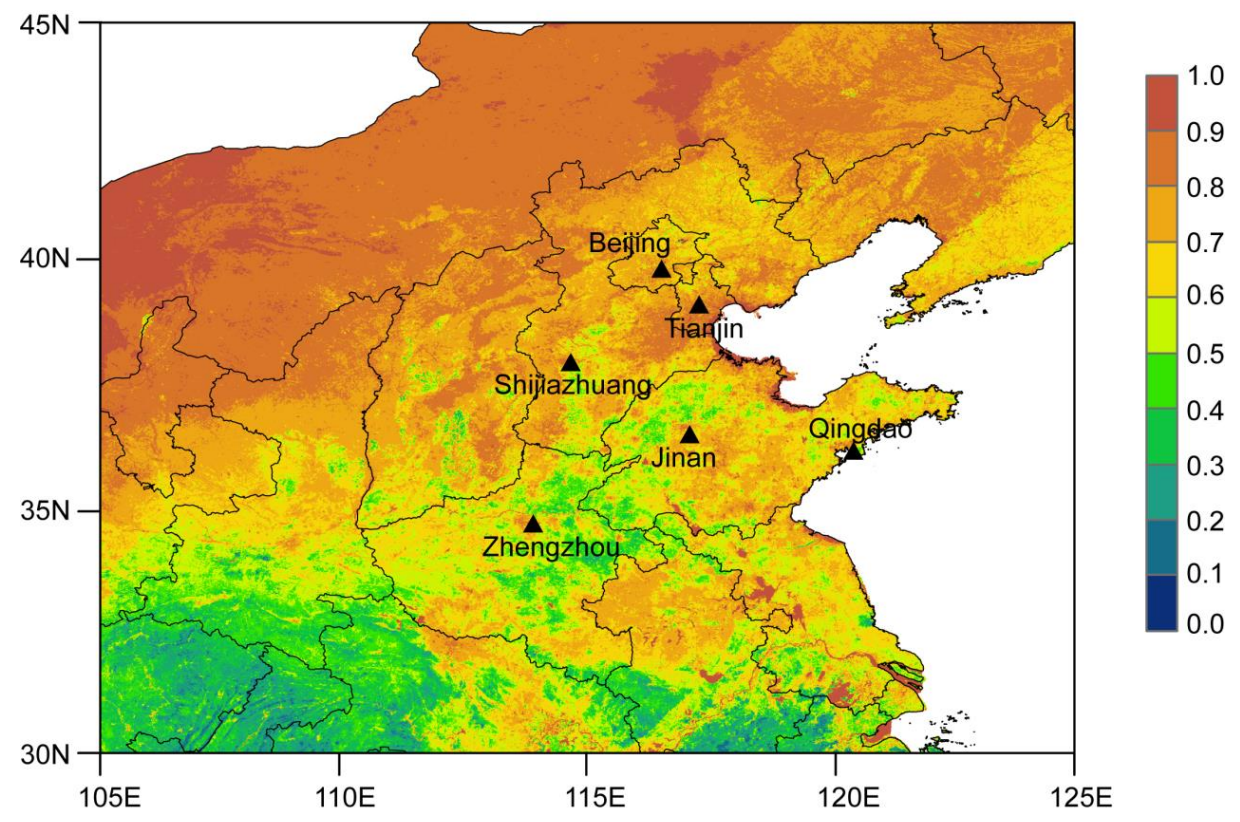

Fig. 1. The normalized differential vegetation index (NDVI) values in northern China in November 2018 with the black triangles marking the study city locations. The lower NDVI values indicate a lower ground vegetation cover and vice versa. 
conditions. The sounding data, which was directly obtained from the University of Wyoming (UWYO) website (http://weather.uwyo.edu/upperair/sounding.html), included data such as the vertical variations in temperature and $\mathrm{RH}$ detected twice daily at 00:00 and 12:00 UTC in Beijing $\left(39.93^{\circ} \mathrm{N}, 116.28^{\circ} \mathrm{E}\right)$, Jinan $\left(36.70^{\circ} \mathrm{N}, 117.55^{\circ} \mathrm{E}\right)$, Qingdao $\left(36.06^{\circ} \mathrm{N}, 120.33^{\circ} \mathrm{E}\right)$, and Zhengzhou $\left(34.71^{\circ} \mathrm{N}, 113.65^{\circ} \mathrm{E}\right)$. In addition, the National Centers for Environmental Prediction (NCEP) Final (FNL) Operational Global Analysis data $\left(1.0^{\circ} \times 1.0^{\circ}\right.$ resolution $)$ were adopted in this study in the large-scale wind field analysis of the dust event (https://rda.ucar.edu/datasets/ds083.2/index.html).

\section{Satellite Data}

The Moderate Resolution Imaging Spectroradiometer (MODIS) on the Terra and Aqua satellites is an important sensor that provides many atmospheric parameters by the radiance in 36 spectral bands from $0.4-14.4 \mu \mathrm{m}$. The MODIS true-color images provided by Terra and Aqua (satellites covering northern China twice every day at approximately 11:00 and 13:00 local time with $1 \mathrm{~km}$ spatial resolution) could show the major regions affected by hazefog and airborne dust (Engel-Cox et al., 2004; Hsu et al., 2006; Qu et al., 2006). The Collection 6.1 Level 2 MODIS enhanced Deep Blue algorithm (MYD04) provides $10 \mathrm{~km}$ aerosol data on the Deep Blue aerosol optical depth (AOD) at $550 \mathrm{~nm}$ from November 23 till 30 and was used to analyze the haze and dust pollution over northern China. The Ångström exponent $(\alpha)$ provides information about the particle size. A larger $\alpha$ value indicates the presence of smaller particles in the atmosphere and vice versa. The $\alpha$ value was adopted to distinguish the fine particles and dust aerosols in this study. The Cloud-Aerosol Lidar with Orthogonal Polarization (CALIOP) on board the CloudAerosol Lidar Pathfinder Satellite Observation (CALIPSO) provides the global vertical structure and optical property observation data for the aerosol and cloud layers (Vaughan et al., 2004; Omar et al., 2009). The CALIPSO algorithms rely on the optical properties of aerosols integrated with the surface type and layer altitude to determine the aerosol subtype, including smoke, dust, polluted dust (dust and smoke), clean and polluted continents, and clean marine. The daily Level 25 km Vertical Feature Mask Version 4.20 Product observed by the CALIPSO Lidar was used to study the formation process of regional pollution. Since the observations over northern China are not available on November 27, we only chose the periods of November 2326 and November 28-29 in this study. The normalized differential vegetation index (NDVI) could accurately reflect the ground vegetation cover, based on the data from the Système Probatoire d'Observation de la Terre (SPOT) VEGETATION instrument and MODIS, which could diagnose the vegetation cover in the dust source area. The NDVI data are retrieved from the Data Center for Resources and Environmental Sciences website (http://www.resdc.cn). Lower NDVI values indicate lower ground vegetation cover and vice versa. Fig. 1 shows the NDVI spatial distribution in northern China $\left(30-45^{\circ} \mathrm{N}, 105-125^{\circ} \mathrm{E}\right)$. It is clear that in November 2018, the vegetation cover in the northern part of
North China, especially in Inner Mongolia, is relatively low, which provides favorable surface conditions for the production of dust events.

\section{The Definition of Pollution Events}

The Chinese Meteorological Administration distinguishes fog and haze based on the visibility and $\mathrm{RH}$, whereby haze is defined as visibility $<10 \mathrm{~km}$ and $\mathrm{RH}<80 \%$ and fog is defined as visibility $<10 \mathrm{~km}$ and RH $>90 \%$. When RH is between $80 \%$ and $90 \%$, fog and haze are mixing (Tao et al., 2014b; Wang et al., 2015; Han et al., 2016). The Chinese Meteorological Administration distinguishes dust events through the visibility and wind speed. It is difficult to distinguish dust events from haze events solely by using the visibility and wind speed. For example, the criteria for floating dust are defined as visibility $<10 \mathrm{~km}$ at a wind speed $<5.4 \mathrm{~m} \mathrm{~s}^{-1}$. This is similar to the criteria for haze weather. Therefore, the $\mathrm{PM}_{2.5} / \mathrm{PM}_{10}$ ratio and $\mathrm{PM}_{10}$ concentration were also simultaneously adopted to distinguish dusty days from haze pollution events in this study. The ratio of the $\mathrm{PM}_{2.5}$ concentration to the $\mathrm{PM}_{10}$ concentration was between 0.19 and 0.58 on dusty days in previous studies (Fu et al., 2010; Li et al., 2017; Tian et al., 2018). For the dust event from November 25 till 26, 2018, Ma et al. (2019) found that the $\mathrm{PM}_{2.5}$-to- $\mathrm{PM}_{10}$ concentration ratio in the northern regions decreased to 0.41 . Therefore, in this study, a dusty day was defined as one with a $\mathrm{PM}_{2.5} / \mathrm{PM}_{10}$ ratio $<0.4$; moreover, the $\mathrm{PM}_{10}$ concentration was also applied to adjust the duration of the episodes.

\section{RESULT AND DISCUSSION}

\section{Pollutant Concentration Variation}

Due to its unique topography, the Beijing-Tianjin-Hebei region is prone to haze events. In addition, the dust activities in Inner Mongolia also affect the air quality in this region. In this study, an episode was chosen from November 23 till 30, 2018, including haze-fog and dusty days. Fig. 2 shows the MODIS true-color images captured by Terra and Aqua satellites during this period. The true-color images indicate that on November 23, northern China was relatively clean; however, on November 24, haze clouds appeared from south to north that gradually covered the whole eastern part of North China from November 25 till 26. Simultaneously, dust clouds appeared in central Inner Mongolia on November 26 , indicating the appearance of desert dust that spread to the southeast afterward, which coincided with the study of Ma et al. (2019). The high $\mathrm{PM}_{10}$ level shown in Fig. S1 also proved the occurrence of the dust event. As shown in Fig. 3, except for Qingdao, the daily $\mathrm{PM}_{2.5}$ concentration of each city was higher than $75 \mu \mathrm{g} \mathrm{m}^{-3}$ after November 23 . Even in Qingdao, the hourly $\mathrm{PM}_{2.5}$ concentration often exceeded $75 \mu \mathrm{g} \mathrm{m}^{-3}$ after November 23. Moreover, the daily $\mathrm{PM}_{2.5}$ concentration in Shijiazhuang, Zhengzhou and Tianjin exceeded $115 \mu \mathrm{g} \mathrm{m}^{-3}$ from November 24 till 26. According to Fig. 3, the change in air quality can be divided into two stages, namely, haze-fog and dust in northern China, and the air quality transition occurred on November 27. From November 23 till 26, the change in air quality can be roughly 


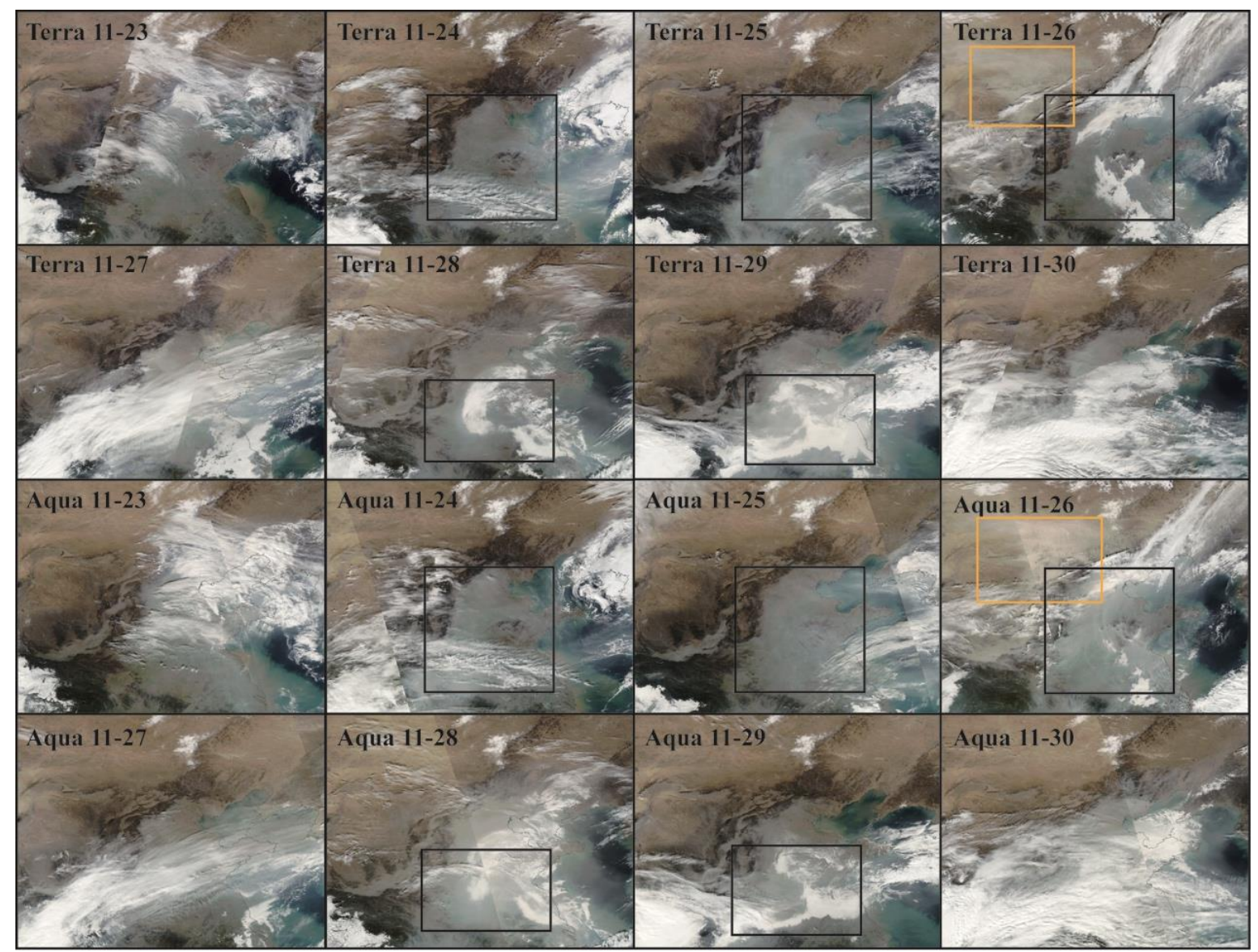

Fig. 2. Terra and Aqua $1 \mathrm{~km}$ MODIS true-color images during the haze-fog-dust events over North China. The black squares mark the haze clouds with a low visibility and a high $\mathrm{PM}_{2.5}$ concentration below; the yellow squares mark the dust clouds with a high $\mathrm{PM}_{10}$ concentration below.

divided into two groups: The first group concerns the urban agglomeration represented by Beijing, Tianjin and Shijiazhuang, and the second group concerns the urban agglomeration consisting of Jinan, Qingdao and Zhengzhou.

From November 23 till 26, the hourly $\mathrm{PM}_{2.5}$ concentration in the first group gradually increased, reaching a maximum value exceeding $250 \mu_{\mathrm{g} \mathrm{m}}^{-3}$ between the night of November 26 and the early morning of November 27. The high $\mathrm{PM}_{2.5}$ concentration indicated the occurrence of heavy pollution events. In addition, the visibility in the first group was lower than $10 \mathrm{~km}$ from November 23 till 26. Hence, this period can be considered a haze process. In the second group, the $\mathrm{PM}_{2.5}$ concentration increased relatively steadily. Thereafter, in Jinan and Qingdao, the $\mathrm{PM}_{2.5}$ concentration gradually increased beginning on the night of November 26, and the maximum value was attained during the daytime. Regardless of the group, a considerable change in the $\mathrm{PM}_{2.5}$ concentration approximately occurred on November 27 , which was mainly affected by the transport of desert dust.

To further illustrate the trajectory and impact of dust aerosols, the hourly $\mathrm{PM}_{10}$ concentration and the ratio of the $\mathrm{PM}_{2.5}$ concentration to the $\mathrm{PM}_{10}$ concentration in each city from November 23 till 30, 2018, are also shown in Fig. 3. The dust event first occurred in central Inner Mongolia. The desert dust affected Beijing and Tianjin, with a maximum
$\mathrm{PM}_{10}$ concentration exceeding $600 \mu \mathrm{g} \mathrm{m}^{-3}$ in the early morning of November 27, as shown in Fig. 3. During the day of November 27, the desert dust reached Shijiazhuang and Jinan, but there were two peak concentrations in Shijiazhuang; one occurred at midnight before November 26 and the other at 10:00 (BJT) on November 27. The peak at midnight was mainly caused by local emissions during the haze period, while the latter peak was due to the influence of desert dust. From midnight on November 27 till the morning of November 28, desert dust affected Zhengzhou and Qingdao. The dust event first occurred in the middle of Inner Mongolia and then spread southeastward, finally affecting the southern part of North China. Similar to the change in air quality from November 23 till 26, the variation in air quality after November 27 can also be divided into two groups. In Fig. 3, in the second group, after the desert dust reached Shijiazhuang, Jinan, Qingdao, and Zhengzhou, the high $\mathrm{PM}_{10}$ concentration (> $350 \mu \mathrm{g} \mathrm{m}^{-3}$ ) did not decrease as rapidly as that in Beijing and Tianjin (the first group), where it only persisted for approximately 8 hours, whereas in the former areas it remained for longer than 20 hours. This indicates that desert dust remained in the middle and southern part of North China after November 27. Moreover, the hourly $\mathrm{PM}_{2.5}$ concentration in Jinan and Zhengzhou also remained relatively high after November 27. The averaged $\mathrm{PM}_{2.5}$ concentration 


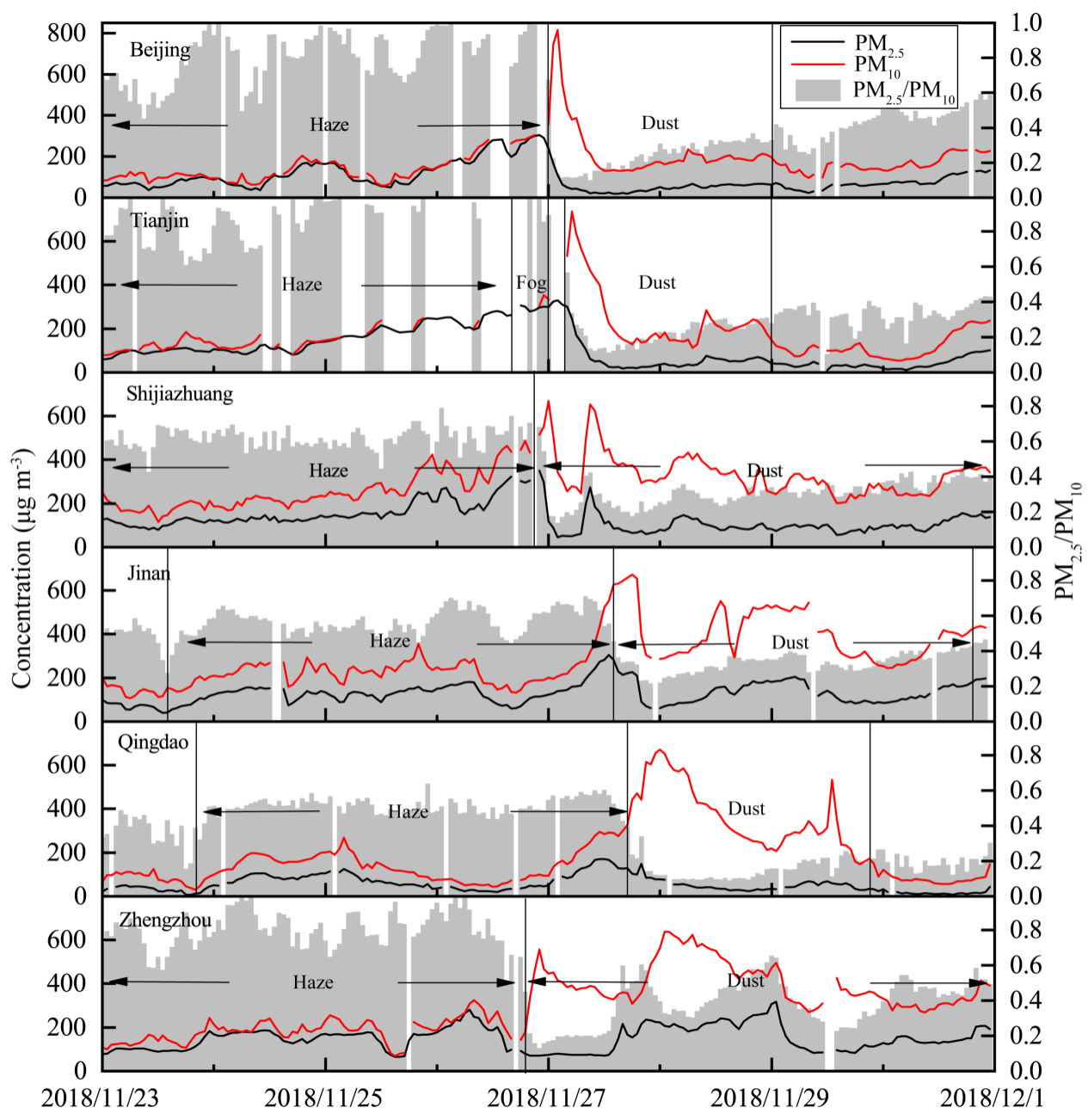

Fig. 3. Hourly $\mathrm{PM}_{2.5}$ (black line) and $\mathrm{PM}_{10}$ (red line) concentrations and hourly $\mathrm{PM}_{2.5} / \mathrm{PM}_{10}$ ratios (gray shadow) in Beijing, Tianjin, Shijiazhuang, Jinan, Qingdao, and Zhengzhou from November 23 till 30, 2018.

in Jinan and Zhengzhou between November 23 and 26 was approximately 114 and $144 \mu \mathrm{g} \mathrm{m} \mathrm{m}^{-3}$, respectively, which increased to 146 and $156 \mu \mathrm{g} \mathrm{m}^{-3}$, respectively, after November 27. It is worth noting that the hourly $\mathrm{PM}_{2.5}$ concentration in Zhengzhou was high, with an average value of approximately $144 \mu \mathrm{g} \mathrm{m}^{-3}$ between November 23 and 26, substantially decreased on the evening of November 26 and increased again after November 27. This trend might be attributed to the effect of two desert dust events: one in the mid-northern part of Gansu occurring on November 25 and the other in the middle of Inner Mongolia occurring on November 26 (Ma et al., 2019). These two dust events are shown in Fig. S1. Compared with the other cities, through the variation in the $\mathrm{PM}_{2.5} / \mathrm{PM}_{10}$ concentration ratio, it is further evident that the proportion of fine particles in Jinan and Zhengzhou remained at a high level, sometimes even higher than 0.4 after November 27. Particularly in Zhengzhou, the $\mathrm{PM}_{2.5} / \mathrm{PM}_{10}$ ratio decreased to below 0.4 at 20:00 (BJT) on November 26 , indicating that the city was in the dust weather stage at this time. At 15:00 (BJT) on November 27, the $\mathrm{PM}_{2.5} / \mathrm{PM}_{10}$ ratio remained at approximately 0.5 , corresponding to the increased $\mathrm{PM}_{2.5}$ concentration. This likely occurred because the mixing of dust and haze promoted a high fine particle concentration in places such as Jinan and Zhengzhou. This generated a higher $\mathrm{PM}_{2.5} / \mathrm{PM}_{10}$ ratio than in other cities.

We also analyzed the variation in the $\mathrm{NO}_{2}$ concentration (Fig. S2). The change in the $\mathrm{NO}_{2}$ concentration was consistent with the change trend of the $\mathrm{PM}_{2.5}$ concentration in the different cities before November 27, mainly because of local anthropogenic emissions (Tao et al., 2014a). After the dust event on the night of November 26, the $\mathrm{NO}_{2}$ and $\mathrm{PM}_{2.5}$ concentrations in the various cities showed clear differences. In the first group, the hourly $\mathrm{NO}_{2}$ concentration exceeded the $\mathrm{PM}_{2.5}$ concentration after November 27, while in the second group, especially in Jinan and Zhengzhou, the $\mathrm{PM}_{2.5}$ concentration considerably increased after November 27, but the $\mathrm{NO}_{2}$ concentration did not; this result may be due to the influence of dust events, including the presence of fine particles due to dust and the heterogeneous chemistry on the dust surface (Dentener et al., 1996; Bauer et al., 2004; Fairlie et al., 2010). This caused $\mathrm{NO}_{2}$ to be consumed as a precursor, thus keeping the $\mathrm{NO}_{2}$ concentration relatively low.

\section{Meteorological Conditions}

The variations in air quality are influenced by local emissions and meteorological conditions. Fig. 4 shows the 


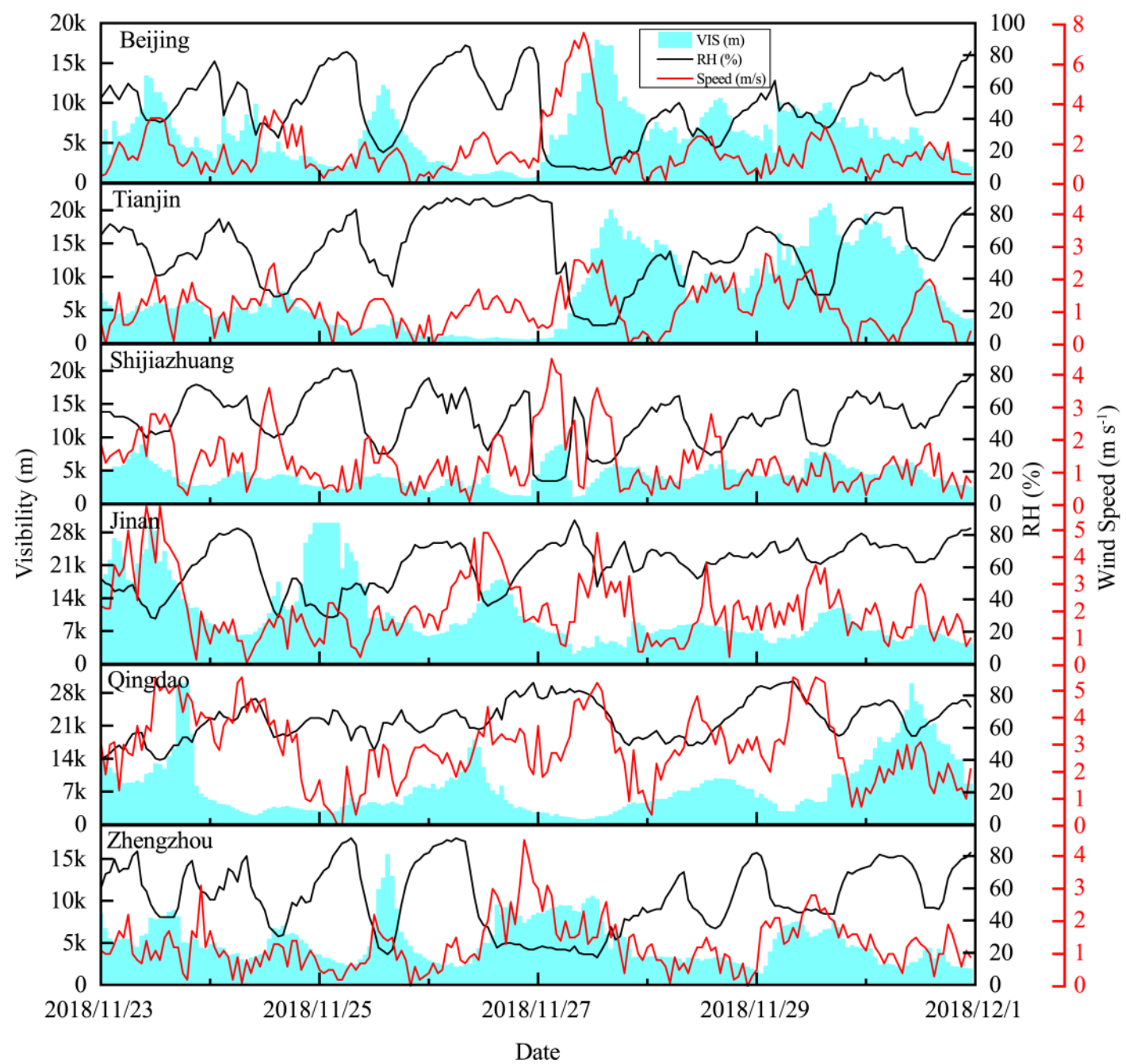

Fig. 4. Hourly values of the visibility (blue shadow), RH (black line), and wind speed (red line) in Beijing, Tianjin, Shijiazhuang, Jinan, Qingdao, and Zhengzhou from November 23 till 30, 2018.

near-surface meteorological conditions in each city, including the horizontal visibility, RH and wind speed. It is evident from November 23, RH was relatively high in all cities, especially from the evening till the early morning, and $\mathrm{RH}$ in most cities exceeded $80 \%$; the high RH provided favorable conditions for the generation of secondary particles (Yang et al., 2015). Correspondingly, the wind speed began to gradually decrease, especially on November 25 and 26, and the lowest wind speed level was attained during the study period; moreover, the visibility was also the lowest at this time, except in Jinan and Qingdao. In Jinan and Qingdao, the wind speed and visibility slightly increased, corresponding to the decrease in $\mathrm{PM}_{2.5}$ concentration from November 25 till 26. After November 27, the meteorological conditions exhibited large discrepancies among the different cities as well as the $\mathrm{PM}_{2.5}$ and $\mathrm{PM}_{10}$ concentrations. Likewise, the meteorological conditions in the cities can be roughly divided into three groups after November 27. The first group is represented by Beijing and Tianjin, which were influenced by northwest winds. In the early morning of November 27 , the wind speed increased, and RH suddenly decreased with a shift in the wind direction to the north, indicating that cold air began to affect these cities. In addition, the visibility began to improve during the daytime of November 27. Moreover, the $\mathrm{PM}_{10}$ concentration increased and the $\mathrm{PM}_{2.5}$ concentration suddenly decreased, indicating the arrival of desert dust transported by cold air (Fig. 3). In addition, the variation in meteorological conditions in Shijiazhuang was noteworthy. Similar to Beijing and Tianjin, sudden wind speed increases and $\mathrm{RH}$ decreases accompanied by the northerlies occurred in the early morning of November 27. However, the visibility did not improve after the cold air invasion. At this time, the high $\mathrm{PM}_{10}$ concentration and low $\mathrm{PM}_{2.5} / \mathrm{PM}_{10}$ ratio indicated that desert dust remained in Shijiazhuang. The second group is represented by Jinan and Qingdao, and the wind direction transitioned from north to east during the dust period. The wind direction changed to the north at 07:00 (BJT) on November 27. Simultaneously, the wind speed increased, which indicated that cold air began to affect Jinan and Qingdao, while RH remained higher than $60 \%$ from November 27 till 30 without a significant decrease. Then, the wind direction turned southeastward at 22:00 (BJT) on November 27 in Jinan, and eastward at 01:00 (BJT) on November 28 in Qingdao. At this time, the downtrend of the 
$\mathrm{PM}_{10}$ concentration had notably weakened, as shown in Fig. 3. With the eastward transition of the wind direction, dust was transported back by the air flow, which again affected Jinan and Qingdao. This phenomenon is called $d u s t$ backflow, which promotes a high $\mathrm{PM}_{10}$ concentration, and the mixing of dust and haze (Xu et al., 2014; Li et al., 2016b; An et al., 2018). In the third group, represented by Zhengzhou, the weather conditions changed differently from those in the other cities. Before November 26, the meteorological conditions in Zhengzhou were similar to those in the first group, with a high RH and a low wind speed and visibility. At noon on November 26, the wind direction changed to the northwest, which brought cold air accompanied by desert dust from the mid-northern part of Gansu; accordingly, this caused the RH to decrease and the wind speed to increase, corresponding to the decrease in $\mathrm{PM}_{2.5}$ concentration. Later, at noon on November 27, the wind direction changed to the northeast, and the wind speed slightly increased. Moreover, the $\mathrm{PM}_{10}$ concentration again increased in the early morning on November 28 (in Fig. 3), indicating the effect of dust backflow on Zhengzhou. The analysis shows that adverse meteorological conditions occurred in North China from November 23 till 26, and cold air accompanied by dust activities on November 27 affected the northern part of North China and caused the meteorological conditions to improve. However, the cold air did not improve the weather conditions in the central and southern parts of North China.
The low surface temperature in autumn and winter slows down the movement of atmospheric molecules, leading to temperature inversion and stable weather conditions. In addition, the high humidity near the ground further aggravates heavy pollution (Liu et al., 2013). Figs. 5 and 6 show the vertical variations in the temperature and $\mathrm{RH}$, respectively, based on the Beijing, Jinan, Qingdao and Zhengzhou sounding station data during the haze-fog-dust event. As shown in Fig. 5, inversions occurred in all areas except in Qingdao from November 24 till 27. There was no distinct inversion layer in Qingdao during the whole study period, which resulted in its diffusion ability in the vertical direction being higher than that in the other places. This absence of an inversion layer partly explained its lower fine particle pollutant concentration than that in other places. The inversion layer in Beijing was first observed at 20:00 on November 24, and did not collapse until November 27. The existence and development of the inversion layer was consistent with the increased $\mathrm{PM}_{2.5}$ concentration and the haze event. The inversion layer collapsed at 08:00 on November 27 because of the cold air invasion, and the diffusion conditions were improved. In Jinan, the inversion intensity decreased from $1.8^{\circ} \mathrm{C} 100-\mathrm{m}^{-1}$ to $1.0^{\circ} \mathrm{C} 100-\mathrm{m}^{-1}$ after November 26 . However, on November 28 , the temperature inversion was strengthened with an inversion intensity of approximately $2.4^{\circ} \mathrm{C} 100-\mathrm{m}^{-1}$ at 08:00 in the surface layer. In Zhengzhou, the inversion layer height was approximately $1000 \mathrm{~m}$ with
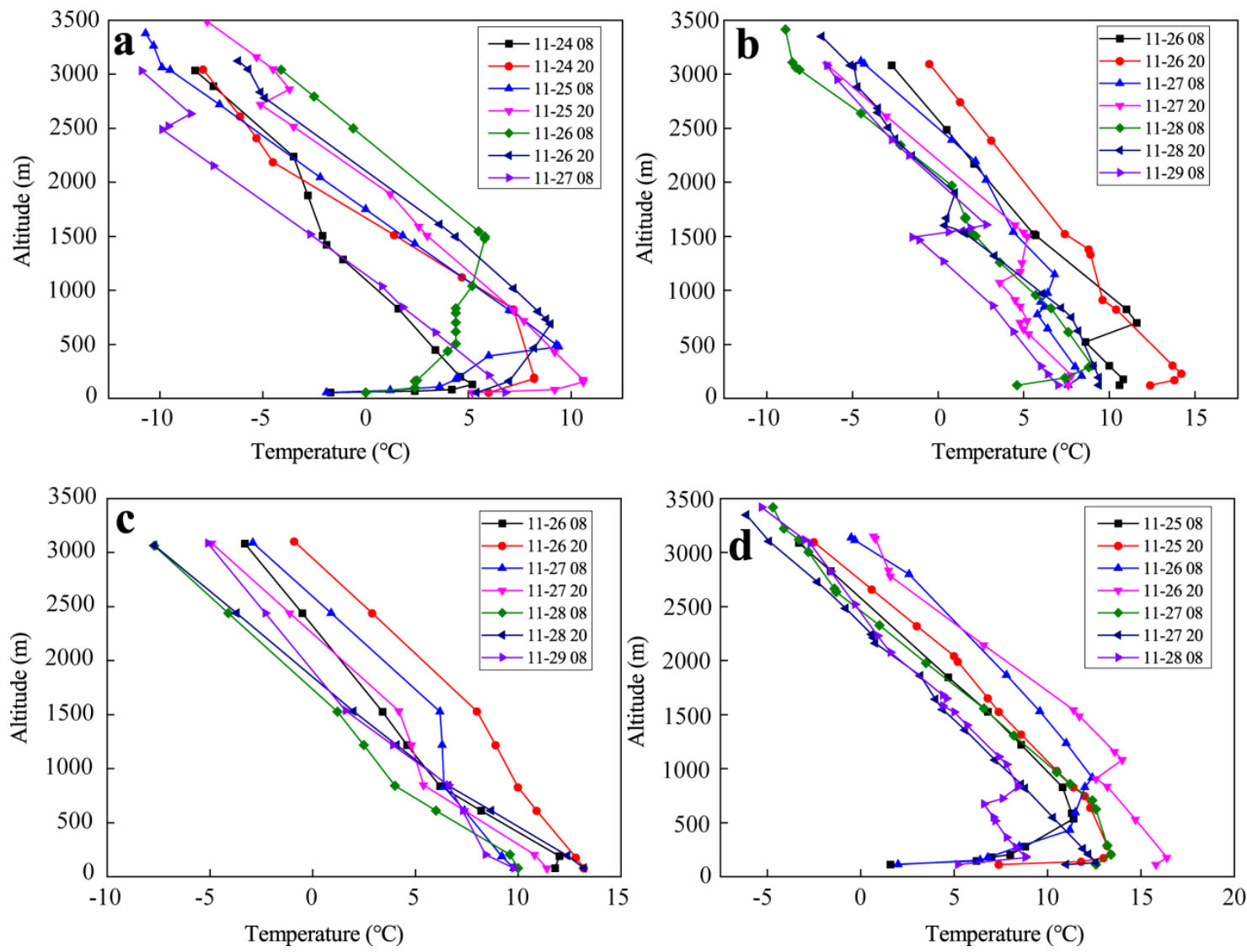

Fig. 5. Vertical distribution of the temperature $\left({ }^{\circ} \mathrm{C}\right.$ ) in (a) Beijing (November 24-27, 2018), (b) Jinan (November 26-29, 2018), (c) Qingdao (November 26-29, 2018), and (d) Zhengzhou (November 25-28, 2018). 

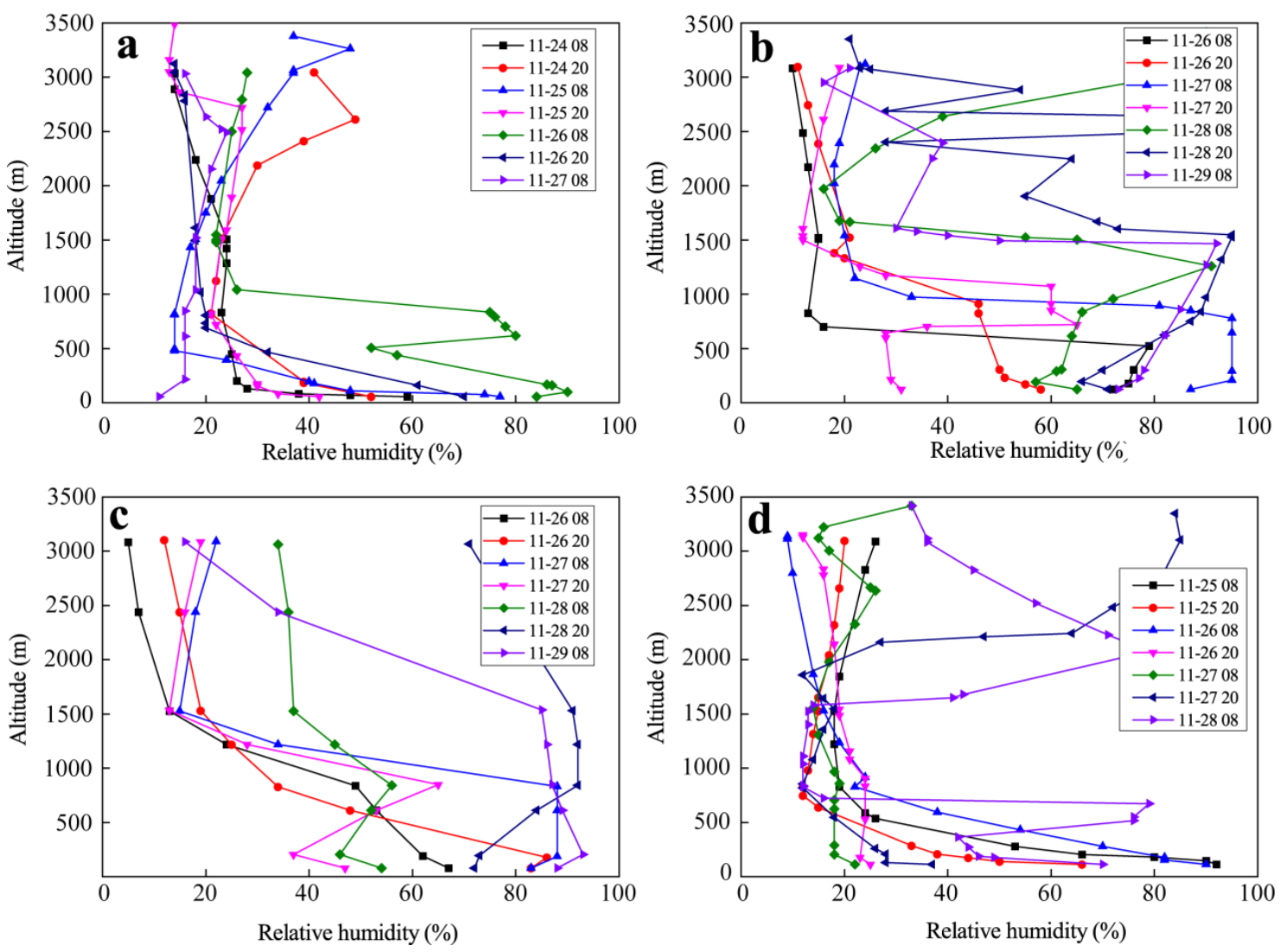

Fig. 6. Vertical distribution of the relative humidity (\%) in (a) Beijing (November 24-27, 2018), (b) Jinan (November 2629, 2018), (c) Qingdao (November 26-29, 2018), and (d) Zhengzhou (November 25-28, 2018).

an inversion intensity of approximately $1.3^{\circ} \mathrm{C} 100-\mathrm{m}^{-1}$ at 08:00 on November 26 and considerably decreased after November 26 due to the effect of the northwest wind. The near-surface inversion layer was strengthened with the inversion intensity increasing from $1.25^{\circ} \mathrm{C} 100-\mathrm{m}^{-1}$ to $4.7^{\circ} \mathrm{C}$ $100-\mathrm{m}^{-1}$ at 08:00 on November 28 as a result of the influence of the northeast wind. The occurrence of an inversion layer does not promote the diffusion of pollutants, which compresses pollutants in the vertical direction and thus aggravates pollution. The existence of an inversion layer in Beijing corresponded to the high $\mathrm{PM}_{2.5}$ concentration from November 24 till 26. Moreover, the strengthening of the inversion layer was accompanied by an increase in the $\mathrm{PM}_{2.5}$ concentration on November 28 in Zhengzhou and Jinan. In Fig. 6, the nearground RH exceeded 60\% from November 24 till 26, and it even exceeded 80\% some of the time at all stations. At 08:00 on November 26, the high-humidity layer even extended to $1 \mathrm{~km}$ above the air in Beijing. However, with the arrival of dust on November 27, which indicated that cold air had arrived, the humidity at each station notably decreased. The high-humidity environment near the ground in Jinan at 08:00 on November 27 corresponded to the high $\mathrm{PM}_{2.5}$ concentration, while the decreased humidity thereafter indicated the occurrence of dust, but the presence of an inversion layer increased the humidity on November 28 with increasing $\mathrm{PM}_{10}$ concentration. Due to the influence of the northwest cold air in Zhengzhou on the afternoon of November 26 , the humidity near the ground notably decreased at 20:00 on November 26. In addition, the $\mathrm{PM}_{10}$ concentration increased and the $\mathrm{PM}_{2.5}$ concentration decreased. However, during the night of November 27, the humidity increased due to the moisture transported by the easterly wind, and the $\mathrm{PM}_{10}$ concentration reached its second highest level. At this time, the $\mathrm{PM}_{2.5}$ concentration did not decrease as it did when affected by the northwest wind. This indicated that an increase in humidity is conducive to the generation of fine particles, which in turn affects the $\mathrm{PM}_{2.5}$ concentration near the ground.

\section{Dust Transport and Impact on the Downstream Areas}

In Fig. 2, dust appeared in Inner Mongolia on November 26, indicating the occurrence of a dust event. Fig. 7 shows that there were two high-AOD centers in North China on November 26: one in the middle of Inner Mongolia with a strong northwest wind at $850 \mathrm{hPa}$, and the other in the Beijing-Tianjin-Hebei region with a weak north wind. The maximum AOD in the latter region exceeded 1.0. On November 27, the high-AOD center in central Inner Mongolia moved southeastwardly with the northwest wind at $850 \mathrm{hPa}$. On November 28, there was an AOD peak with a weak wind field. Moreover, the $\alpha$ value in the two high-AOD centers on November 26 represented contrasting conditions, ranging from 0 to 0.2 in central Inner Mongolia and higher than 1.8 in northern China. The smaller the $\alpha$ value is, the larger the corresponding aerosol particle size is and vice versa. This finding indicates that the high-AOD region in Inner 

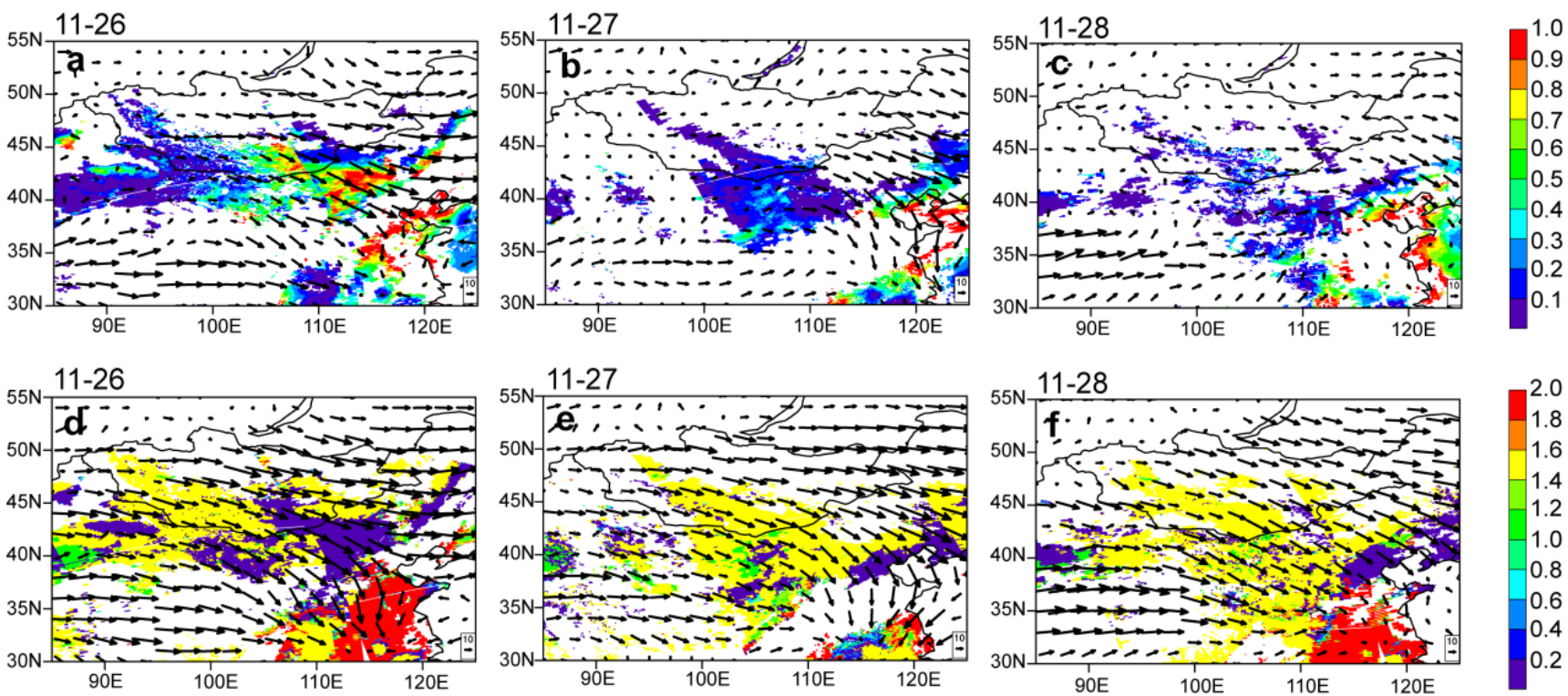

Fig. 7. (a-c) Aqua MODIS $10 \mathrm{~km}$ AOD at $550 \mathrm{~nm}$ with the wind field at $850 \mathrm{hPa}$ and (d-f) the Ångström exponent with the wind field at $700 \mathrm{hPa}$ over northern China on November 26, 27, and 28.

Mongolia on November 26 was characterized by a relatively large particle size, while the particles in North China were relatively small. Moreover, it is also clear that the low- $\alpha$ region gradually moved to the southeast under the influence of the northwest wind at $700 \mathrm{hPa}$ (approximately $3 \mathrm{~km}$ ). Thus, this indicates that the dust clouds gradually moved southward, affecting the downstream area. On November 28, the low- $\alpha$ region $(<0.2)$ continued to move southeastward, but a high- $\alpha$ region ( $>1.8$ ) was encountered in a weak wind field at $700 \mathrm{hPa}$. The variations in AOD and $\alpha$ indicated a southeastward trajectory of the dust aerosols from November 26 till 28. With the southeastward movement of dust, the air quality was affected in North China from November 27 till 28. The fine aerosol concentration increased in the southern part of North China.

The CALIPSO satellite can be used to better understand the vertical aerosol subtype distribution. The vertical aerosol subtype over northern China from November 23 till 30 is shown in Fig. 8. The polluted air mass was observed as the satellite passed over Shanxi, Hebei, Henan and Shandong Provinces from November 23 till 25. This corresponds to the local haze-fog event. On November 26, a polluted air mass was still observed in Shandong Province, and dust aerosols were observed in Inner Mongolia and northern Hebei Province. Dust aerosols continued to hover over northern China on November 28 and 29, suggesting that the higher $\mathrm{PM}_{2.5}$ concentration in Zhengzhou and Jinan after November 27 was affected by dust aerosols. According to the previous analysis, the variation in the $\mathrm{PM}_{2.5}$ concentration in each city from November 23 till 28 can be roughly divided into two groups, and the difference between the two groups is mainly noticeable after the dust arrives. As shown in Fig. 8, the dust remained in the central and southern parts of North China for nearly two days, which might provide a longer period for the dust to influence fine particle generation.

As shown in Fig. 3, each city experienced different degrees of haze and dust events. Fig. 9 shows the observed $\mathrm{PM}_{2.5}$ concentration over northern China and the ratio of the observed $\mathrm{PM}_{2.5}$ concentration to the $\mathrm{PM}_{10}$ concentration. The range of the high- $\mathrm{PM}_{2.5}\left(>150 \mu \mathrm{g} \mathrm{m}^{-3}\right)$ area gradually expanded from November 24 till 26, and the $\mathrm{PM}_{2.5}$ concentration in some areas even reached $500 \mu \mathrm{g} \mathrm{m}^{-3}$ on November 26. Then, the $\mathrm{PM}_{2.5}$ concentration decreased as cold air and dust moved south of the study area after November 26. From November 23 till 25, according to the distribution variation in the $\mathrm{PM}_{2.5} / \mathrm{PM}_{10}$ ratio, except in Inner Mongolia, most areas of the region attained values higher than 0.5. On November 26, on the one hand, the high$\mathrm{PM}_{2.5} / \mathrm{PM}_{10}$ range was extended; on the other hand, the $\mathrm{PM}_{2.5} / \mathrm{PM}_{10}$ ratio in Inner Mongolia decreased below 0.3, which corresponded to the occurrence of dust events in Inner Mongolia. Moreover, as time proceeded, the low- $\mathrm{PM}_{2.5} / \mathrm{PM}_{10}$ areas further extended to most of northern China; this change was also related to the movement of dust aerosols. It should be noted that on November 28, although the overall values in northern China decreased below 0.5 , simultaneously, in the southern part of North China, the $\mathrm{PM}_{2.5}$ concentration notably increased from November 27 on. This suggests that local fine particles were generated after the dust aerosols moved downstream. As shown in Fig. 9, the effect of dust on the fine particulate matter observed in Jinan and Zhengzhou is not limited to the two urban stations but is observed across the entire southern part of North China.

\section{Discussion}

In the previous analysis, the pollution process in North China between November 23 and 30 can be roughly divided into two groups. The difference between the two groups is mainly reflected in the influence of dust. In the first group, the cold air was strong, resulting in a relatively high moving speed of the dust aerosols, which is evidenced by the rapid increase and decrease in the wind speed and $\mathrm{PM}_{10}$ 

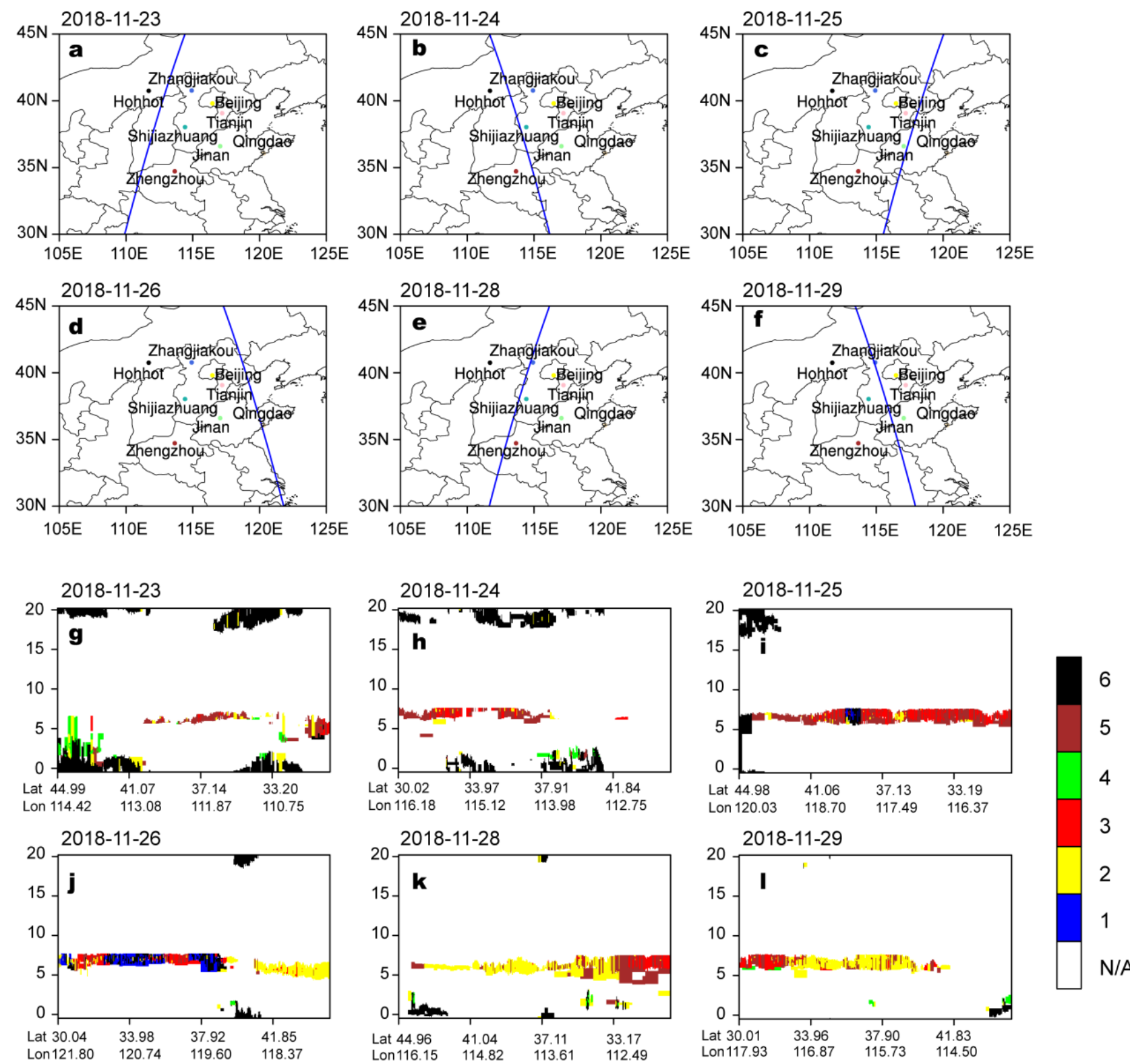

Fig. 8. (a-f) CALIPSO satellite trajectory (blue line) with the colored points marking the study city locations and (g-i) vertical profiles of the classified aerosol subtypes on November 23, 24, 25, 26, 28, and 29, 2018 (N/A = not applicable, $1=$ clean marine, $2=$ dust, $3=$ polluted continental, $4=$ clean continental, $5=$ polluted dust, and $6=$ smoke).

concentration, respectively, in Beijing and Tianjin. In the second group, especially in Jinan and Zhengzhou, the $\mathrm{PM}_{10}$ concentration and wind speed did not increase or decrease as fast as those in the first group. Simultaneously, after November 27, the $\mathrm{PM}_{2.5}$ concentration in Jinan and Zhengzhou remained high. This high $\mathrm{PM}_{2.5}$ concentration is mainly caused by dust.

The influence of dust on the $\mathrm{PM}_{2.5}$ concentration in Jinan and Zhengzhou might persist in two ways. First, the dust layer could partly reduce the solar radiation reaching the surface, which caused a temperature inversion to develop, and this in turn weakened the convection and diffusion of the surface $\mathrm{PM}_{2.5}$ concentration (Mohalfi et al., 1998; Ramanathan et al., 2001; Dunion and Velden, 2004; Satheesh and Moorthy, 2005). In Fig. 5, the temperature inversion layer that remained in Jinan and Zhengzhou after November 28 supports this assumption. Second, when dust is mixed with pollutants, it provides an interface for heterogeneous and catalytic reactions (Dupart et al., 2012; Nie et al., 2012; Nie et al., 2014; Tian et al., 2018). From the variations in the CALIPSO aerosol subtype and hourly $\mathrm{PM}_{10}$ concentration, dust is observed to have remained in Jinan and Zhengzhou for more than 20 hours. Li et al. (2016b) found that the concentration of different soluble inorganic salt ions (such as nitrate and sulfate) increased in the dust backflow period. Yang et al. (2018) found that both remote transmission and secondary formation were the main sources of nitrate during dust storms based on a correlation analysis of nitrate with crustal ions and ammonium. Huang et al. (2010) analyzed the components of $\mathrm{PM}_{2.5}$ and the total suspended particulates (TSP) during long-distance dust transmission and mixing 

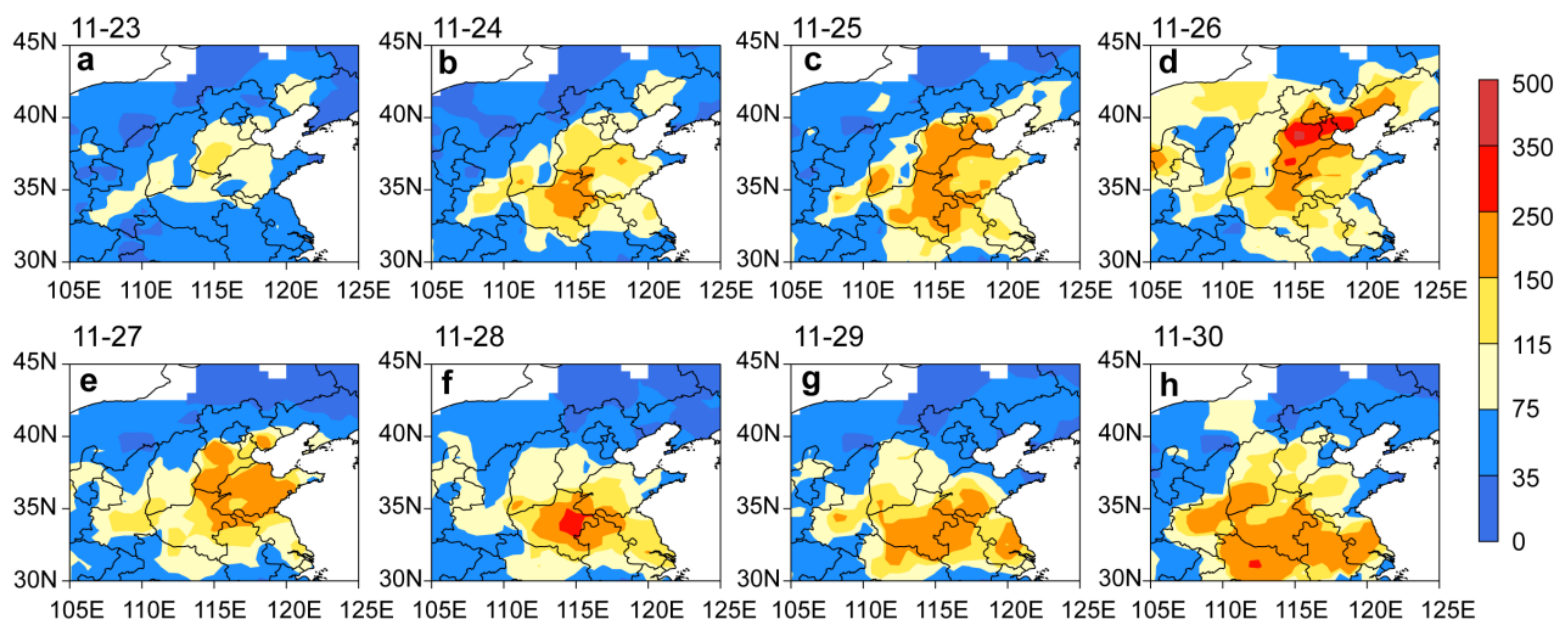

105E 110E 115E 120E 125E 105E 110E 115E 120E 125E 105E 110E 115E 120E 125E 105E 110E 115E 120E 125E
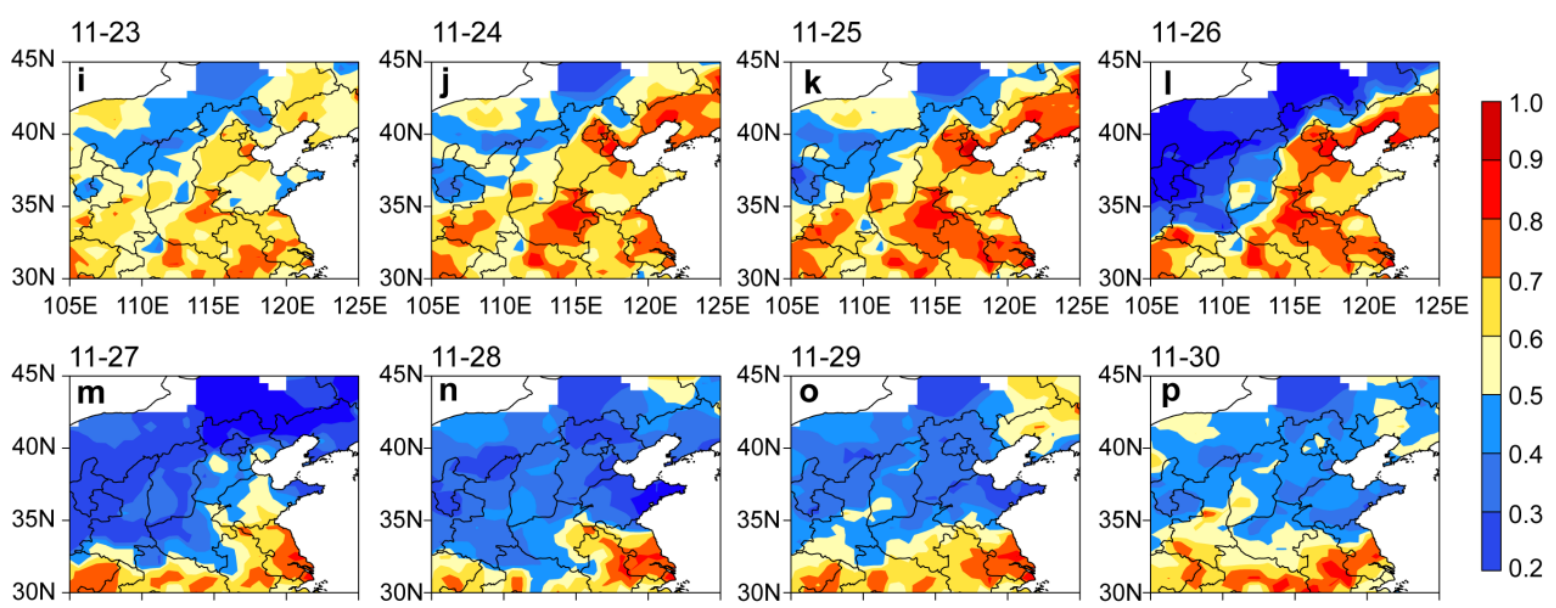

105E 110E 115E 120E 125E 105E 110E 115E 120E 125E 105E 110E 115E 120E 125E 105E 110E 115E 120E 125E

Fig. 9. $(\mathrm{a}-\mathrm{h})$ Daily interpolated distributions of the observed $\mathrm{PM}_{2.5}$ concentration and (i-p) $\mathrm{PM}_{2.5} / \mathrm{PM}_{10}$ ratio near the surface over northern China from November 23 till 30, 2018.

with air pollutants in western, northern, and eastern China from March 20 till April 20, 2007. They found that the secondary sulfate concentration during dust storms was higher than the value on non-dusty days, which might be due to the heterogeneous reactions on the dust surface. The mixture of dust and pollutants was carried by the dust backflow, and they remained in Jinan and Zhengzhou for a long period of time. This phenomenon might allow the reaction to be carried out to a greater extent and promote the production of nitrate and sulfate; thus, there was an increase in the $\mathrm{PM}_{2.5}$ concentration. More studies are needed to improve our understanding of the role of dust aerosols in regional heavy pollution over northern China and their interactions in the future. In particular, modeling research could obtain the quantified contribution level of the heterogeneous processes to heavy pollution.

\section{CONCLUSION}

This study investigated a regional haze-fog-dust event that occurred in North China from November 23 till November 30 of 2018 . The influence and the trajectory of the haze-fog and the dust were evaluated with satellite and air quality observation data, and the evolution of the hazefog event was analyzed with surface and vertical meteorological observation data. The effect of dust activity was also concurrently examined.

Based on their variations in air quality between November 23 and November 30, the affected cities of North China can be roughly categorized into two groups for the haze-fog-dust event: Beijing, Tianjin, and Shijiazhuang, and Jinan, Qingdao, and Zhengzhou. In the first group, the $\mathrm{PM}_{2.5}$ concentrations gradually increased from November 23 till November 27, reaching their maximum values during the night of November 26 and the early morning of November 27 , after which they decreased with the arrival of cold air. In the second group, no notable elevation was detected in the $\mathrm{PM}_{2.5}$ levels between November 23 and November 27, but they rose considerably after the latter date. The averaged $\mathrm{PM}_{2.5}$ concentrations in Jinan and Zhengzhou were approximately 114 and $144 \mu \mathrm{g} \mathrm{m}^{-3}$, respectively, between November 23 and November 26 but increased to 146 and $156 \mu \mathrm{g} \mathrm{m}^{-3}$ following November 27. The variation in the $\mathrm{PM}_{10}$ concentration and the $\mathrm{PM}_{2.5} / \mathrm{PM}_{10}$ ratio in each city, the distribution of the AOD and Angström indexes, and the CALIPSO vertical profiles of the classified aerosol subtypes all indicated that the dust observed during 
this pollution episode moved southeastward and remained in the central and southern parts of North China for nearly two days.

Our analysis of the meteorological observation data confirms that static and stable weather conditions promote the occurrence and development of haze-fog events, including the episode assessed in this study. Although the intrusion of cold air accompanied by dust on November 27 affected the northern part of North China, increasing the air quality in this area, it did not improve meteorological conditions in the central or southern part. Instead, continuous adverse conditions and the dust backflow trapped dust aerosols in the southern part of this region for nearly two days and were responsible for the high $\mathrm{PM}_{2.5}$ concentrations there after November 27.

Adverse meteorological conditions and pollutant emissions are the primary causes of haze-fog events, and cold air typically accompanies the endings of such episodes during autumn and winter. However, the arrival of strong cold air also occasionally results in dust events, which influence the formation of fine particles in downstream areas and lead to an increase in the concentration of this fraction, especially when combined with a dust backflow and persistent adverse conditions. Modeling studies are needed to quantify the role and interactions of dust aerosols in the heavy regional pollution across North China.

\section{ACKNOWLEDGMENT}

This research was supported by the National Natural Science Foundation of China (Nos. 41771242 and 41705135), the Natural Science Foundation of Tianjin (18JCYBJC23100), the Major Science and Technology Projects in Tianjin (18ZXAQSF00130, 18ZXSZSF00160), and the Beijing Natural Science Foundation (8194078). We thank the Ministry of Ecology and Environment of the People's Republic of China, China Meteorological Data Service System, Data Center for Resources and Environmental Sciences, UWYO, CALIPSO, and MODIS for the data used in our work. The authors also thank the anonymous reviewers for their constructive comments in improving this work.

\section{SUPPLEMENTARY MATERIAL}

Supplementary data associated with this article can be found in the online version at https://doi.org/10.4209/aaqr.2 019.11.0567

\section{REFERENCES}

An, L., Zhang, H., Gui, H. and Zhang, T. (2018). Analysis of a sand and dust weather process affecting north China and Huanghuai in spring 2015. Meteorol. Mon. 44: 180 188. (in Chinese with English Abstract)

Andreae, M.O., Schmid, O., Yang, H., Chand, D., Yu, J.Z., Zeng, L.M. and Zhang, Y.H. (2008). Optical properties and chemical composition of the atmospheric aerosol in urban Guangzhou, China. Atmos. Environ. 42: 63356350. https://doi.org/10.1016/j.atmosenv.2008.01.030
Bauer, S.E., Balkanski, Y., Schulz, M., Hauglustaine, D.A. and Dentener, F. (2004). Global modeling of heterogeneous chemistry on mineral aerosol surfaces: Influence on tropospheric ozone chemistry and comparison to observations. J. Geophys. Res. 109: D02304. https://doi.o rg/10.1029/2003JD003868

Chan, C.K. and Yao, X. (2008). Air pollution in mega cities in China. Atmos. Environ. 42: 1-42. https://doi.org/10.10 16/j.atmosenv.2007.09.003

Chen, Y.Y., Ebenstein, A., Greenstone, M. and Li, H.B. (2013). Evidence on the impact of sustained exposure to air pollution on life expectancy from China's Huai River policy. Proc. Natl. Acad. Sci. U.S.A. 110: 12936-12941. https://doi.org/10.1073/pnas.1300018110

Dentener, F.J., Carmichael, G.R., Zhang, Y., Lelieveld, J. and Crutzen, P.J. (1996). Role of mineral aerosol as a reactive surface in the global troposphere. J. Geophys. Res. 101: 22869-22889. https://doi.org/10.1029/96JD01818

Dunion, J.P. and Velden, C.S. (2004). The impact of the Saharan air layer on Atlantic tropical cyclone activity. Bull. Amer. Meteorol. Soc. 85: 353. https://doi.org/10.11 75/BAMS-85-3-353

Dupart, Y., King, S.M., Nekat, B., Nowak, A., Wiedensohler, A., Herrmann, H., David, G., Thomas, B., Miffre, A., Rairoux, P., D'Anna, B. and George, C. (2012). Mineral dust photochemistry induces nucleation events in the presence of $\mathrm{SO}_{2}$. Proc. Natl. Acad. Sci. U.S.A. 109: 20842-20847. https://doi.org/10.1073/pnas.1212297109

Engel-Cox, J.A., Holloman, C.H., Coutant, B.W. and Hoff, R.M. (2004). Qualitative and quantitative evaluation of MODIS satellite sensor data for regional and urban scale air quality. Atmos. Environ. 38: 2495-2509. https://doi.org/10.1016/j.atmosenv.2004.01.039

Fairlie, T.D., Jacob, D.J., Dibb, J.E., Alexander, B., Avery, M.A., van Donkelaar, A. and Zhang, L. (2010). Impact of mineral dust on nitrate, sulfate, and ozone in transpacific Asian pollution plumes. Atmos. Chem. Phys. 10: 39994012. https://doi.org/10.5194/acp-10-3999-2010

Fan, Q., Shen, C., Wang, X.M., Li, Y., Huang, W., Liang, G.X., Wang, S.Y. and Huang, Z.E. (2013). Impact of a dust storm on characteristics of particle matter (PM) in Guangzhou, China. Asia-Pac. J. Atmos. Sci. 49: 121-131. https://doi.org/10.1007/s13143-013-0013-2

Fu, Q.Y., Zhuang, G.S., Li, J.A., Huang, K., Wang, Q.Z., Zhang, R., Fu, J., Lu, T., Chen, M., Wang, Q.A., Chen, Y., $\mathrm{Xu}, \mathrm{C}$. and $\mathrm{Hou}, \mathrm{B}$. (2010). Source, long-range transport, and characteristics of a heavy dust pollution event in Shanghai. J. Geophys. Res. 115: D00K29. https://doi.org/10.1029/2009JD013208

Fu, Q.Y., Zhuang, G.S., Wang, J., Xu, C., Huang, K., Li, J., Hou, B., Lu, T. and Streets, D.G. (2008). Mechanism of formation of the heaviest pollution episode ever recorded in the Yangtze River Delta, China. Atmos. Environ. 42: 20232036. https://doi.org/10.1016/j.atmosenv.2007.12.002

Ginoux, P., Chin, M., Tegen, I., Prospero, J.M., Holben, B., Dubovik, O. and Lin, S.J. (2001). Sources and distributions of dust aerosols simulated with the GOCART model. $J$. Geophys. Res. 106: 20255-20273. https://doi.org/10.102 9/2000JD000053 
Griffin, D.W. (2007). Atmospheric movement of microorganisms in clouds of desert dust and implications for human health. Clin. Microbiol. Rev. 20: 459-477. https://doi.org/10.1128/CMR.00039-06

Guo, S., Hu, M., Zamora, M.L., Peng, J.F., Shang, D.J., Zheng, J., Du, Z.F., Wu, Z., Shao, M., Zeng, L.M., Molina, M.J. and Zhang, R.Y. (2014). Elucidating severe urban haze formation in China. Proc. Natl. Acad. Sci. U.S.A. 111: 17373-17378. https://doi.org/10.1073/pnas.1419604111

Han, F., Xu, J., He, Y.J., Dang, H.Y., Yang, X. and Meng, F. (2016). Vertical structure of foggy haze over the Beijing-Tianjin-Hebei area in January 2013. Atmos. Environ. 139: 192-204. https://doi.org/10.1016/j.atmosen v.2016.05.030

Han, S.Q., Wu, J.H., Zhang, Y.F., Cai, Z.Y., Feng, Y.C., Yao, Q., Li, X.J., Liu, Y.W. and Zhang, M. (2014). Characteristics and formation mechanism of a winter haze-fog episode in Tianjin, China. Atmos. Environ. 98: 323-330. https://doi.org/10.1016/j.atmosenv.2014.08.078

Hsu, N.C., Tsay, S.C., King, M.D. and Herman, J.R. (2006). Deep blue retrievals of Asian aerosol properties during ACE-Asia. IEEE Trans. Geosci. Remote Sens. 44: 31803195. https://doi.org/10.1109/TGRS.2006.879540

Huang, K., Zhuang, G.S., Li, J.A., Wang, Q.Z., Sun, Y.L., Lin, Y.F. and Fu, J.S. (2010). Mixing of Asian dust with pollution aerosol and the transformation of aerosol components during the dust storm over China in spring 2007. J. Geophys. Res. 115: D00K13. https://doi.org/10.1 029/2009JD013145

Huang, R.J., Zhang, Y.L., Bozzetti, C., Ho, K.F., Cao, J.J., Han, Y.M., Daellenbach, K.R., Slowik, J.G., Platt, S.M., Canonaco, F., Zotter, P., Wolf, R., Pieber, S.M., Bruns, E.A., Crippa, M., Ciarelli, G., Piazzalunga, A., Schwikowski, M., Abbaszade, G., Schnelle-Kreis, J., Zimmermann, R., An, Z.S., Szidat, S., Baltensperger, U., El Haddad, I. and Prevot, A.S.H. (2014). High secondary aerosol contribution to particulate pollution during haze events in China. Nature 514: 218-222. https://doi.org/10.1038/nature13774

Huebert, B.J., Bates, T., Russell, P.B., Shi, G.Y., Kim, Y.J., Kawamura, K., Carmichael, G. and Nakajima, T. (2003). An overview of ACE-Asia: Strategies for quantifying the relationships between Asian aerosols and their climatic impacts. J. Geophys. Res. 108: 8633. https://doi.org/10.1 029/2003JD003550

Kaiser, D.P. and Qian, Y. (2002). Decreasing trends in sunshine duration over China for 1954-1998: Indication of increased haze pollution? Geophys. Res. Lett. 29: 381-38-4. https://doi.org/10.1029/2002GL016057

Li, H.M., Wang, Q.G., Shao, M., Wang, J.H., Wang, C., Sun, Y.X., Qian, X., Wu, H.F., Yang, M. and Li, F.Y. (2016a). Fractionation of airborne particulate-bound elements in haze-fog episode and associated health risks in a megacity of southeast China. Environ. Pollut. 208: 655-662. https://doi.org/10.1016/j.envpol.2015.10.042

Li, J., Wang, Z.F., Zhuang, G., Luo, G., Sun, Y. and Wang, Q. (2012). Mixing of Asian mineral dust with anthropogenic pollutants over East Asia: A model case study of a superduststorm in March 2010. Atmos. Chem. Phys. 12: 75917607. https://doi.org/10.5194/acp-12-7591-2012
Li, S., Pan, T., Yan, J., Meng, F., Chen, Y., Yang, X. and Zhang, W. (2016b). Analysis of a Sand Dust Weather Process in Beijing in Spring 2015. Environ. Sci. Technol. 39: 137-143. (in Chinese) https://kns.cnki.net/KCMS/de tail/detail.aspx?filename $=$ fjks $201604027 \&$ dbname $=$ CJF D\&dbcode $=$ CJFQ

Li, X.L., Ma, Y.J., Wang, Y.F., Liu, N.W. and Hong, Y. (2017). Temporal and spatial analyses of particulate matter $\left(\mathrm{PM}_{10}\right.$ and $\left.\mathrm{PM}_{2.5}\right)$ and its relationship with meteorological parameters over an urban city in northeast China. Atmos. Res. 198: 185-193. https://doi.org/10.1016 /j.atmosres.2017.08.023

Liu, B.M., Ma, Y.Y., Gong, W., Zhang, M. and Yang, J. (2018). Study of continuous air pollution in winter over Wuhan based on ground-based and satellite observations. Atmos. Pollut. Res. 9: 156-165. https://doi.org/10.1016/j. apr.2017.08.004

Liu, X.G., Li, J., Qu, Y., Han, T., Hou, L., Gu, J., Chen, C., Yang, Y., Liu, X., Yang, T., Zhang, Y., Tian, H. and Hu, M. (2013). Formation and evolution mechanism of regional haze: A case study in the megacity Beijing, China. Atmos. Chem. Phys. 13: 4501-4514. https://doi.org/10.5194/acp13-4501-2013

Ma, S.Q., Zhang, X.L., Gao, C., Tong, Q.S., Xiu, A.J., Zhao, H.M. and Zhang, S.C. (2019). Simulating performance of CHIMERE on a late autumnal dust storm over northern China. Sustainability 11: 1074. https://doi.org/10.3390/su 11041074

Mohalfi, S., Bedi, H.S., Krishnamurti, T.N. and Cocke, S.D. (1998). Impact of shortwave radiative effects of dust aerosols on the summer season heat low over Saudi Arabia. Mon. Weather Rev. 126: 3153-3168. https://doi.org/10.11 75/1520-0493(1998)126<3153:IOSREO>2.0.CO;2

Nie, W., Ding, A.J., Wang, T., Kerminen, V.M., George, C., Xue, L.K., Wang, W.X., Zhang, Q.Z., Petaja, T., Qi, X.M., Gao, X.M., Wang, X.F., Yang, X.Q., Fu, C.B. and Kulmala, M. (2014). Polluted dust promotes new particle formation and growth. Sci. Rep. 4: 6. https://doi.org/10.10 38/srep06634

Nie, W., Wang, T., Xue, L.K., Ding, A.J., Wang, X.F., Gao, X.M., Xu, Z., Yu, Y.C., Yuan, C., Zhou, Z.S., Gao, R., Liu, X.H., Wang, Y., Fan, S.J., Poon, S., Zhang, Q.Z. and Wang, W.X. (2012). Asian dust storm observed at a rural mountain site in southern China: Chemical evolution and heterogeneous photochemistry. Atmos. Chem. Phys. 12: 11985-11995. https://doi.org/10.5194/acp-12-11985-2012

Omar, A.H., Winker, D.M., Kittaka, C., Vaughan, M.A., Liu, Z.Y., Hu, Y.X., Trepte, C.R., Rogers, R.R., Ferrare, R.A., Lee, K.P., Kuehn, R.E. and Hostetler, C.A. (2009). The CALIPSO automated aerosol classification and lidar ratio selection algorithm. J. Atmos. Oceanic Technol. 26: 1994-2014. https://doi.org/10.1175/2009JTECHA1231.1

Prospero, J.M., Ginoux, P., Torres, O., Nicholson, S.E. and Gill, T.E. (2002). Environmental characterization of global sources of atmospheric soil dust identified with the Nimbus 7 Total Ozone Mapping Spectrometer (TOMS) absorbing aerosol product. Rev. Geophys. 40: 2-1-2-31. https://doi.org/10.1029/2000RG000095

Qu, J.J., Hao, X.J., Kafatos, M. and Wang, L.L. (2006). 
Asian dust storm monitoring combining terra and aqua MODIS SRB measurements. IEEE Geosci. Remote Sens. Lett. 3: 484-486. https://doi.org/10.1109/LGRS.2006.87 7752

Quan, J., Zhang, Q., He, H., Liu, J., Huang, M. and Jin, H. (2011). Analysis of the formation of fog and haze in North China Plain (NCP). Atmos. Chem. Phys. 11: 8205-8214. https://doi.org/10.5194/acp-11-8205-2011

Ramanathan, V., Crutzen, P.J., Kiehl, J.T. and Rosenfeld, D. (2001). Atmosphere - Aerosols, climate, and the hydrological cycle. Science 294: 2119-2124. https://doi.o rg/10.1126/science.1064034

Satheesh, S.K. and Moorthy, K.K. (2005). Radiative effects of natural aerosols: A review. Atmos. Environ. 39: 20892110. https://doi.org/10.1016/j.atmosenv.2004.12.029

Sullivan, R.C., Guazzotti, S.A., Sodeman, D.A. and Prather, K.A. (2007). Direct observations of the atmospheric processing of Asian mineral dust. Atmos. Chem. Phys. 7: 1213-1236. https://doi.org/10.5194/acp-7-1213-2007

Sun, Y.L., Zhuang, G.S., Wang, Y., Zhao, X.J., Li, J., Wang, Z.F. and An, Z.S. (2005). Chemical composition of dust storms in Beijing and implications for the mixing of mineral aerosol with pollution aerosol on the pathway. $J$. Geophys. Res. 110: D24209. https://doi.org/10.1029/200 5JD006054

Sun, Y.L., Wang, Z.F., Fu, P.Q., Yang, T., Jiang, Q., Dong, H.B., Li, J. and Jia, J.J. (2013). Aerosol composition, sources and processes during wintertime in Beijing, China. Atmos. Chem. Phys. 13: 4577-4592. https://doi.org/10.5194/acp13-4577-2013

Tao, M.H., Chen, L.F., Wang, Z.F., Ma, P.F., Tao, J.H. and Jia, S.L. (2014a). A study of urban pollution and haze clouds over northern China during the dusty season based on satellite and surface observations. Atmos. Environ. 82: 183-192. https://doi.org/10.1016/j.atmosenv.2013.10.010

Tao, M.H., Chen, L.F., Xiong, X.Z., Zhang, M.G., Ma, P.F., Tao, J.H. and Wang, Z.F. (2014b). Formation process of the widespread extreme haze pollution over northern China in January 2013: Implications for regional air quality and climate. Atmos. Environ. 98: 417-425. https://doi.org/10.1016/j.atmosenv.2014.09.026

Tian, Y., Pan, X.L., Nishizawa, T., Kobayashi, H., Uno, I., Wang, X.Q., Shimizu, A. and Wang, Z.F. (2018). Variability of depolarization of aerosol particles in the megacity of Beijing: implications for the interaction between anthropogenic pollutants and mineral dust particles. Atmos. Chem. Phys. 18: 18203-18217. https://doi.org/10.5194/acp-18-18203-2018

Uno, I., Eguchi, K., Yumimoto, K., Takemura, T., Shimizu, A., Uematsu, M., Liu, Z.Y., Wang, Z.F., Hara, Y. and Sugimoto, N. (2009). Asian dust transported one full circuit around the globe. Nat. Geosci. 2: 557-560. https://doi.org/10.1038/ngeo583

Vaughan, M., Young, S., Winker, D., Powell, K., Omar, A., Liu, Z.Y., Hu, Y.X. and Hostetler, C. (2004). Fully automated analysis of space-based lidar data: An overview of the CALIPSO retrieval algorithms and data products. Proc. SPIE 5575, Laser Radar Techniques for Atmospheric Sensing. https://doi.org/10.1117/12.572024
Wang, G.H., Zhang, R.Y., Gomez, M.E., Yang, L.X., Zamora, M.L., Hu, M., Lin, Y., Peng, J.F., Guo, S., Meng, J.J., Li, J.J., Cheng, C.L., Hu, T.F., Ren, Y.Q., Wang, Y.S., Gao, J., Cao, J.J., An, Z.S., Zhou, W.J., ... Molina, M.J. (2016). Persistent sulfate formation from London Fog to Chinese haze. Proc. Natl. Acad. Sci. U.S.A. 113: 13630-13635. https://doi.org/10.1073/pnas.1616540113

Wang, M.Y., Cao, C.X., Li, G.S. and Singh, R.P. (2015). Analysis of a severe prolonged regional haze episode in the Yangtze River Delta, China. Atmos. Environ. 102: 112-121. https://doi.org/10.1016/j.atmosenv.2014.11.038

Wang, Y.S., Yao, L., Wang, L.L., Liu, Z.R., Ji, D.S., Tang, G.Q., Zhang, J.K., Sun, Y., Hu, B. and Xin, J.Y. (2014). Mechanism for the formation of the January 2013 heavy haze pollution episode over central and eastern China. Sci. China Earth Sci. 57: 14-25. https://doi.org/10.1007/ s11430-013-4773-4

Xu, W., Li, Y., Sun, R., Dong, X. and Qiu, Q. (2014). Impact characteristics of a typical dust backflow weather on the air quality in Beijing. Acta Sci. Circumst. 34: 297-302. (in Chinese)

Yang, J., Niu, Z.Q., Shi, C.E., Liu, D.Y. and Li, Z.H. (2010). Microphysics of atmospheric aerosols during winter haze/fog events in Nanjing. Environ. Sci. 31: 1425-1431. (in Chinese with English Abstract)

Yang, Y., Li, X.R., Chen, X., Liu, S.Q., Liu, Y.S., Xu, J., Wang, L.L., Tao, M.H. and Wang, G.H. (2018). Analysis of Different Particle Sizes, Pollution Characteristics, and Sources of Atmospheric Aerosols During the Spring Dust Period in Beijing. Environ. Sci. 39: 5315-5322. (in Chinese with English Abstract) https://doi.org/10.13227/j. hjkx.201804237

Yang, Y.R., Liu, X.G., Qu, Y., An, J.L., Jiang, R., Zhang, Y.H., Sun, Y.L., Wu, Z.J., Zhang, F., Xu, W.Q. and Ma, Q.X. (2015). Characteristics and formation mechanism of continuous hazes in China: A case study during the autumn of 2014 in the North China Plain. Atmos. Chem. Phys. 15: 8165-8178. https://doi.org/10.5194/acp-15-8165-2015

Zhang, R.H., Li, Q. and Zhang, R.N. (2014). Meteorological conditions for the persistent severe fog and haze event over eastern China in January 2013. Sci. China Earth Sci. 57: 26-35. https://doi.org/10.1007/s11430-013-4774-3

Zhang, R.J., Arimoto, R., An, J.L., Yabuki, S. and Sun, J.H. (2005). Ground observations of a strong dust storm in Beijing in March 2002. J. Geophys. Res. 110: D18S06. https://doi.org/10.1029/2004JD004589

Zhang, X.Y., Wang, Y.Q., Niu, T., Zhang, X.C., Gong, S.L., Zhang, Y.M. and Sun, J.Y. (2012). Atmospheric aerosol compositions in China: Spatial/temporal variability, chemical signature, regional haze distribution and comparisons with global aerosols. Atmos. Chem. Phys. 12: 779-799. https://doi.org/10.5194/acp-12-779-2012

Zhao, X.J., Zhao, P.S., Xu, J., Meng, W., Pu, W.W., Dong, F., He, D. and Shi, Q.F. (2013). Analysis of a winter regional haze event and its formation mechanism in the North China Plain. Atmos. Chem. Phys. 13: 5685-5696. https://doi.org/10.5194/acp-13-5685-2013

Zheng, G.J., Duan, F.K., Su, H., Ma, Y.L., Cheng, Y., Zheng, B., Zhang, Q., Huang, T., Kimoto, T., Chang, D., 
Poschl, U., Cheng, Y.F. and He, K.B. (2015). Exploring the severe winter haze in Beijing: the impact of synoptic weather, regional transport and heterogeneous reactions. Atmos. Chem. Phys. 15: 2969-2983. https://doi.org/10.51 94/acp-13-5685-2013
Received for review, December 16, 2019

Revised, March 19, 2020

Accepted, April 19, 2020 